\title{
The Effects of The Global Financial Crisis on Jordanian Bank
}

\author{
Abdullah Majed Al Maani* \\ Mohammad Haroun Eid Alamarat**
}

*) Abdullah Majed Al Maani Jordanian Bachelor's degree in accounting / university of Al-Hussein Bin Talal Jordan 2009Academic expertise and administrative xperience:-Lecturer/ balqa applied university / college undergraduate maan

**)Mohammad Haroun Eid Alamarat Nationality: Jordanian Bachelor's degree in economics / university of jamia millia islamia /india 1991. Masters degree in economics / university of Kanpur /india 1993

Shadi99su@yahhoo.com 


\section{Abstract:}

This study focused on one of the important issues, namely the impact of the global financial crisis on the banks of Jordan, through the study of its impact on the set of variables and profitability of the bank and the bank's capital.

The study was based on a set of books, studies and articles and research to clarify this issue and the definition and concepts related to them.

The results of the study that the global financial crisis has affected the capital of the banks and the Jordanian and profitability is slightly negative.

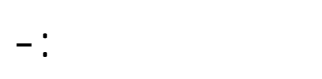

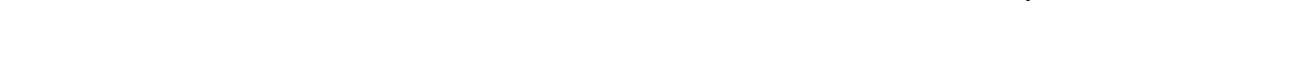

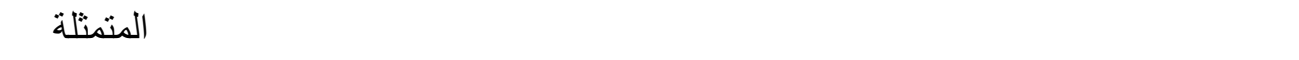

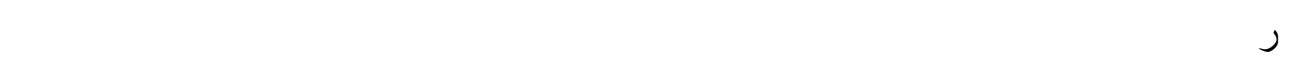

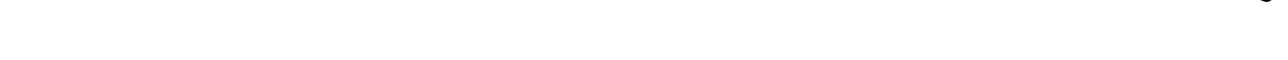

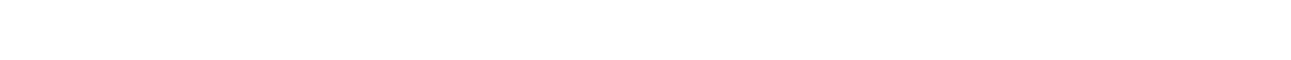

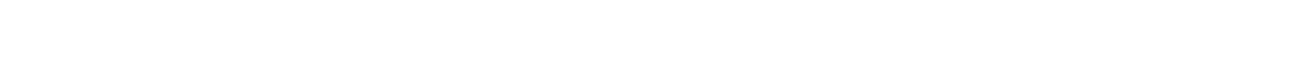

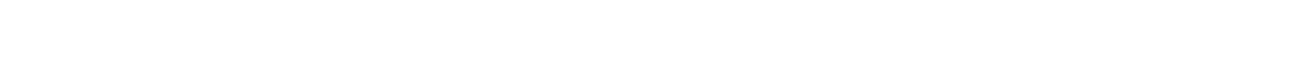

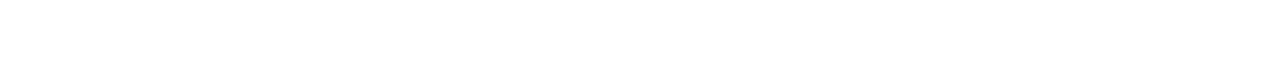

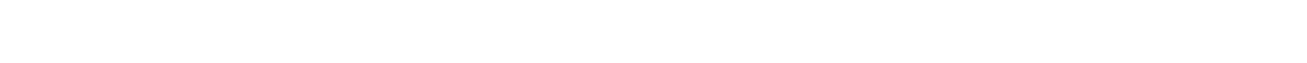

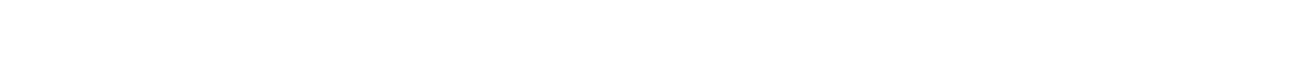

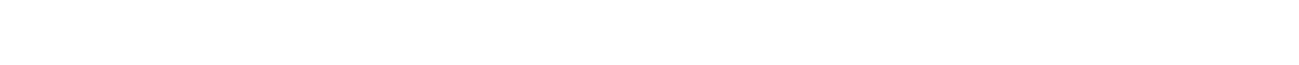
ورلسمالها

ربحيتها 


\section{Chapter One \\ Introduction \\ Problem of the study \\ Objectives of the study \\ The importance of the study \\ Hypotheses of the study \\ Model study}

\section{introduction:}

This crisis is the result of poor financial management resulting from the tendency to the expansion of financial markets, which were not within the logical controls, taking into account the implications of the implications of The law of diminishing returns, and thus produced the problem of the mortgage in the United States, caused by bad real estate loans, and since that date, and extend and worsen the crisis hit throughout the global economy, despite the considerable efforts made by central banks in the United States and the European Union and in the States Asia, despite the support of developing countries and the oil states of the financial institutions out of the crisis.

And the fact that this crisis did not respond significantly with the efforts to overcome them, began to talk about the prospects for entry into the U.S. economy and hence the global economy in a phase of stagnation or recession, with the slowdown in growth rates, the decline in employment opportunities, especially since this crisis is a crisis different from the previous many of the crises experienced by the global economy as the result of a fall in demand, especially on the real estate sector, the spread of bad debts that led to the collapse of a large number of financial institutions and real estate around the world.

\section{Problem of the study}

try to identify the effects of the global financial crisis on Jordanian banks Through the profitability of the bank and the bank's capital.

It is expected the study to answer the following question : What is the impact of the global financial crisis on the banks of Jordan?

\section{Objectives of the study}

The research seeks to study the impact of the global financial crisis on the banks of Jordan by: 
1. Impact profitability of Jordanian banks.

2. Impact on the capital of Jordanian banks.

3. Providing a base of information to understand the impact of the crisis to take the necessary measures to deal with this crisis.

\section{The importance of the study:}

1. The importance of the study stems from the importance of the banking system, a Jordanian who is considered one of the main pillars of the Jordanian economy.

2. 2. The findings of the study will help the banks, especially the central bank to take the necessary measures in the aftermath of the global financial crisis.

3. The desire of Jordanian banks in maintaining the highest levels in the light of the global financial crisis.

\section{Hypotheses of the study:}

H0: There is no effect to the global financial crisis on the current profitability of the banks of Jordan.

H0:: There is no effect to the global financial crisis on the capital of Jordanian.

\section{Model study:}

Independent variable:

The dependent variable:

\begin{tabular}{|l|l|}
\hline $\begin{array}{l}\text { The global financial } \\
\text { crisis. }\end{array}$ & $\begin{array}{l}\text { 1. Profitability. } \\
\text { 2.Capital. }\end{array}$ \\
\hline
\end{tabular}

\section{Methodology of the study}

This study is based on the books, articles, and research and previous studies to explain the crisis and its impact and the associated terminology to facilitate understanding.

The research consists of 3 basic units:

1. Introduction: Include the research problem and the importance of research and its goals and assumptions upon which the study methodology and the basic components.

2. Literature study: The previous studies in the field of research and everything related to the problem of search of information.

3. The results obtained for the guardian and recommendations to help solve the problem. 


\section{Chapter two \\ framework \\ Literature study}

\section{Procedural definitions:}

- The global financial crisis: the crisis Fallout from the mortgage crisis that surfaced in 2007 because of the failure of millions of borrowers to buy houses and real estate in the United States to pay their debts to banks and led to a strong jolt to the U.S. economy, reaching consequences to the economies of Europe and Asia.

- Profitability: means ability to make profit from all the business activities of an organization, or an enterprise. It shows how efficiently the management can make profit by using all the resources available in the market.

- Capital is the economic term is intended to funds and materials and tools necessary to create economic or commercial activity and the objective of the project, profit or the media or humanitarian work.

\section{Financial crisis:}

The term financial crisis is applied broadly to a variety of situations in which some financial institutions or assets suddenly lose a large part of their value. In the 19th and early 20th centuries, many financial crises were associated with banking panics, and many recessions coincided with these panics. Other situations that are often called financial crises include stock market crashes and the bursting of other financial bubbles, currency crises, and sovereign defaults Financial crises directly result in a loss of paper wealth; they do not directly result in changes in the real economy unless a recession or depression follows.( Mannuel Hinds, 1998).

Many economists have offered theories about how financial crises develop and how they could be prevented. There is little consensus, however, and financial crises are still a regular occurrence around the world.

\section{Subprime mortgage crisis:}

The US subprime mortgage crisis was one of the first indicators of the late2000s financial crisis, characterized by a rise in subprime mortgage delinquencies and foreclosures, and the resulting decline of securities backing said mortgages.

Approximately $80 \%$ of U.S. mortgages issued to subprime borrowers were adjustable-rate mortgages. After U.S. house sales prices peaked in mid-2006 and began their steep decline forthwith, refinancing became more difficult. 
As adjustable-rate mortgages began to reset at higher interest rates, mortgage delinquencies soared. Securities backed with mortgages, including subprime mortgages, widely held by financial firms, lost most of their value. Global investors also drastically reduced purchases of mortgage-backed debt and other securities as part of a decline in the capacity and willingness of the private financial system to support lending. Concerns about the soundness of U.S. credit and financial markets led to tightening credit around the world and slowing economic growth in the U.S. and Europe( Richard W.2008).

\section{Capital Basel:}

In order to improve the degree of measuring the solvency of the banks in the world, endorsed the Basel Committee in 1988 what is known as the standard of "Basel 1", which set standards process and applied to measure the solvency of each bank and integrity of the bank, based in the determination of the amount of capital and to compare the size of risky assets risk-weighted within and outside the budget, so that at least the amount of capital of 8 per cent. In 1999, developed the Basel Committee on the criterion of "Basel 1" to what is known today as the standard of "Basel 2 " to cope with the new phase that the world is witnessing the rise not only in degrees of financial risk, but even in the operational risk and credit risk and market risk management, where the standard "Basel 2" through the use of advanced methods for measuring both credit risk and market risk and operational risk, to determine levels of required capital for the bank.(Reda Abu Hamad,2002)

Because of the global financial crisis that has befallen the world in 2008, it was agreed organizers of the Basel Committee on Banking Supervision on a set of new rules that would work to increase the capital to the extent that it is imperative that the banks keep a reserve, to enable the bank to cope with potential losses, have been identified final timetable is in the first of January (Jan) 2013 for the progressive implementation of the rules are rules, known as "Basel 3", so adhere to the full application in 2019.

Central Bank of Jordan has encouraged banks to provide financing for corporate investment to continue its operations, and apply the standards of the Basel 2 and prepare for the implementation of Basel 3, including help in the progress of the domestic banking industry and upgrade to the ranks of the world's in a rapidly changing world.( Adli Kandah,2008). And contribute to the response of the Jordanian banks in these standards and their commitment to modernity and keeping pace with the competition, with the accession of banks and Arab banks and international to the Jordanian 
market evidence of the growing ability of banks to work and to meet the different needs.

In a later development, in a move aimed at achieving greater financial solvency and cash to the banks licensed in the Kingdom, including increases strength and durability by strengthening their financial positions and the face of any dues future ruling was issued Central Bank of Jordan in mid-December of the year 2010, ie before the end of the same year, serving raise capital of Jordanian banks to 100 million dinars in the minimum instead of 40 million while raising capital branches of foreign banks operating in the Kingdom to 50 million dinars instead of 20 million dinars, the minimum comes $\mathrm{CBE}$ decision in this regard to enhance the size of the capital of banks.

\section{Capital of Jordanian banks before the end of 2011}

The official data issued by the Central Bank by the end of the first month of the year 2011 The volume of capital of banks in the Kingdom, including the benefits and allowances deducted from profit rose summarized to about 5204 million Dinar with the end of January of the year 2011 for about 4949 million dinars at the end of the year 2010 as banking sources expected to double the size of the capital of banks operating in the Kingdom with the end of 2011, the deadline for banks to raise their capital in accordance with the requirements of Central Bank of Jordan as it will reach levels much higher than recorded in the current time in light of the decision of the central raised the minimum capital banks to become the most had the ability and willingness to face any future risk(Association of Banks in Jordan,2011)

The 11 banks locally ranging from capital between 100 and 534 million dinars, and 5 banks capital less than that. To the analyst, investment in the Jordan National Bank Murad Hijazin, that Jordanian banks with less capital for 50 million dinars, you need to double effort in order to raise capital especially those that do not have assets sufficient backup. He revealed that the proportion of profits retained profits from a very high and higher than 75 percent and this is what enhances bank reserves, alluding to the possibility that banks resort to the option of raising the paid up capital of a strategic partner. And the effects of raising capital in the position of the banks stressed that this measure will contribute to facilitate the granting of credit, and increase solvency and reduce the risk of liquidity and raise the rates of profitability. 


\section{Profitability of banks:}

Some believe that it should be aimed at facilities like banks work to achieve maximum profitable or maximize profit Maximization of profit whereas the other believes that the banks service institutions of the national economy and thus should not make a profit. And a third group sees the need for the Bank aims to make profits on the basis that profit and economic functions and that it is necessary to strike a balance between the profit on the grounds that his job between the economic and liquidity(zyad Ramadan,mahfoz jawdeh,2000).

\section{profit Functions :}

Economic function of profit:

first:It is imperative for banks to achieve a profit of profits and economic functions (Khalil Mohammed.1995).

Profits necessary to offset the risk to the bank so he can stay in the business world. Risk of banjs multiple and may be mentioned the following risks:

1. risks of credit and investments.

Is the risk of non-response clients for loans granted to them in spite of the existence of procedures for the collection intact. And risks associated with deterioration of the value of the investment or portfolio of securities. Although diversification. In spite of the precision with which observed by banks in the examination of applications for customers and their financial ... But it is not easy to predict the impact of wars on the national economy and its impact on the loans.

2.risks of compulsory liquidation:

The customer demand for money and the new funds may force the bank to dispose of the assets of the value of the loss. And that the central bank can cover emergency needs similar.

The customer demand in the season like most to change what is happening in deposits from one bank to another as a result of the nature of the operations themselves, and the bank can refuse a loan application to a client of his clients excellent or adult.

3.risk of theft and embezzlement:

These risks exist in any facility where people have long worked under financial pressure, and social and ethical ... And the existence of systems of internal control and internal audit and insurance against theft, and others reduce this risk to the least extent possible Germinate does not render it invalid. 
4.risk of a surprise:

Such as unexpected break records and Aldoissehat and Archive and the facilities available and even in the case of a double records in places other hands, some of these risks can not really expect. And must obtain the Bank's profits to cover all of these risks and Germinate to cover the risks that it was not possible for management to overcome them. And are outside the scope of its control. And can not imagine that the profit necessary to cover poor management and Germinate profit necessary to cover the residual risks after the administration to take all necessary precautions and procedures for each type of risk. Second: The profits are necessary to obtain the capital needed in the future and that of three ways:

1.reinvestment of profits continuously. And is a means of self-funding ..

2.encourage owners of capital in the bank at the IPO to increase its capital. 3.contributor to give an acceptable return on capital increases the confidence in the bank, which contributes to it.

Third: Measure profit efforts that have been made, In general we can say that he spoke profits increased indicates that the effectiveness of the efforts and success of management real profits, not profits from the exploitation of customers or users, or change in the systems of valuation of assets or the transfer of expenses of the current year for years to come, or as a result of circumstances not management were the cause of the "war". And the achievement of the Bank's profit increases confidence not only to the owners of capital and Germinate depositors.

\section{Profitability measures:}

Can measure the profitability of banks following standards:

1.Rate of return on the right of ownership.

2. Rate of return on deposits.

3. Rate of return on the funds available "for hire" .

4. Rate of return on investment.

\section{rate of return on the right of ownership:}

reached by dividing the average yield "profit for the year ending" to the funds owned "property right" and there is disagreement in the right of ownership to be entered in the account, it is the number of title shown in the balance and is the figure includes profit for the year ending? Or should ask year profit of it on the grounds that the profits achieved the end of the year and therefore were not profits funds have been employed, preferably taking 
up half of the profits only, and put the number right of ownership apparent budget end of the year on the grounds that the average of the funds that have been hired and becomes the rate of return on the property right as follows:

$=$ Profit for the year ended X 100

Property rights

And shame on the way that this title was not all the funds available to recruit and Germinate deposits are the largest source of funds that are employed.

\section{rate of return on deposits:}

$=$ Profit for the year ending X 100

\section{Deposits}

And shame at this rate that deposits do not represent all the funds available for recruitment.

\section{Rate of return on investment:}

This measures the average over the profitability achieved by the bank to invest its assets in its various activities. So-called-dropped rate of return on total assets, is calculated rate of return on investment by dividing the net income (net profit after tax) on total assets, as follows:

Rate of return on investment $=$ Net income $\times 100$

Total assets

Return on average equity at the rate of about $16 \%$ and return on average assets $6.1 \%$ all of which are indicators of higher than those internationally accepted.

Going back to the economic and financial conditions that prevailed during the years 2008 - 2010 the indicators and financial statements of the Chairperson of the Arab Bank show significant progress and refers to the growth of assets (45.6 to 51) billion dollars, and increase the rights of property of (7.5 to 8.3) billion dollars, and the high balance of deposits from (31.4 to 35.7) billion, and boosted the bank's portfolio of facilities overall (23.4 to 24) billion dollars, and the percentage of facilities to deposit (63\%).

These indicators confirm the continuation of the senior management of the Bank to pursue a policy of prudent conservative toward the budget items to keep the funds of shareholders and depositors and development, at 
the same time play an effective role in providing funds for various purposes, uses and continue to provide banking products and services to meet the bank's customers in a rapidly changing world.

Jordanian banks have achieved good profitability in the two years (2008 - 2010), despite the repercussions of the financial crisis on the global economy, and records of the banking sector, Jordan's growth exceeds the growth rate of the local economy, which registered the key indicators of the banks progress paves the way for other sectors to recover and move forward despite setbacks and temporary In different sectors of the securities and real estate and trade.At the sectoral level increased net profits by the major banks announced their budgets for the fiscal year by $28 \%$, where most profits are distributed to shareholders as dividends in contributing to this broadcast confidence among shareholders and dealers at the ASE(khaled alzubidi,2011)

At the end of last year achieved a range of licensed banks net profits rewarding in the forefront of Arab, housing, Cairo, Amman, Jordan Kuwait, and Jordan Ahli, Jordan, Jordanian Islamist, and others confirmed the efficacy of banking management and control of prudent monetary policy is represented by the Central Bank of Jordan, which performs operations according to Global standards for the protection of the banking system, and development needs at the macro level.

In this context, the Arab Bank, which spread its branches Arab and international levels and the financial positions of the main around the world forms the backbone of the banking system Jordanian with backlog of mutual trust with customers individuals, institutions, and productive work in the Jordanian economy extends to eight decades, and constitute a key ingredient in the market value of the ASE And the index of prices in the market has achieved operating results are described as good and qualify the bank to increase in net profit for the current fiscal year.

A strict reading of the performance of the Arab Bank for contracts for the past eight reminiscent of the biography of self-made with the beginning of the last century, biography bus wealth of administrative and banking and adhesion-ness and Jordan even said senior bankers and economists «Jordan and the Arab Bank in the same boat», during the last year, work continued on the banking and corporate social responsibility which the bank almost seven million dinars included different sectors, the Arab Bank Jordan highly productive tree.

The other hand, economists considered the high activity and profitability of banks by $28 \%$ the end of 2010 Kmwhariaks level of 
economic activity in the Kingdom the high profits of Jordanian banks is in itself a positive sign refers to the improved economic conditions in the Kingdom, recovery and exit of the recession and economic slowdown, announcing the start of stage recovery

The high profits of Jordanian banks by $28 \%$ in sync with high volume levels of bank deposits at banks and in excess of 5.22 billion dinars, with the end of 2010 in addition to the high volume of facilities to 6.14 Mlyardinar compared with 3.13 billion dinars was recorded at the end of 2009 with record outstanding volume of credit facilities granted by the licensed banks until the end of February of the year 2011, up an unprecedented record, surpassing the amount of 7.14 billion dinars

While the private sector resident in the Kingdom of the lion's share of them, amounting to facilities existing to date to 3.13 billion dinars, while the share of private sector non-resident some 980 million dinars, while the public sector (central government), reaching its share of some 116 million dinars, public institutions, about 338 million while it was the share of nonbank institutions less fortunate, to reach 12 million, comes the resurgence in credit facilities through the index and the direction is rampant, and what he refers to is equal to the movement and recovery of the domestic banking market to coincide with the economic growth in the Kingdom in accordance with current prices, according to economists. From previous studies that the subject of attention of casting the global financial crisis and the financial crisis and its impact on banks in Jordan:

1. STUDY for (Juditlh, 1999) The bank's ability to pay in cash all of its obligations business, and to respond to requests for credit, or grant new loans, and this requires availability of cash at banks, or access it through liquidate some of its assets, or converted into cash means of quickly and easily.

2. A study for (KUNT, 1991) Financial banking crisis as a period where most of the banks in case of insolvency or illiquidity.

3.the study (Mahmoud Juma,.2009), The impact of the crisis on the Jordanian banking sector is limited as a result for her own that Special expertise and experience and because the banking system does not suffer from a lack of liquity but Versa has excess liquidity. The Central Bank as a precaution and the transfer of deposits from U.S. banks to the Central Bank Federal Reserve eased the effects of the crisis.

4. As well as the study came (samer sinokort, 1993) The impact of the global financial crisis on the Jordanian economy The process of conversion of loans into bonds that are not in Jordan are not trading 
securities such as mortgage securities among investors. Also that the process of granting mortgage loans received by the reservation severe Jordanian banks, and therefore should not be linked between the mortgage crisis in America with the Jordanian markete.

5. (Adli Kandah, 2009) The global financial crisis - the most prominent financial bailouts The Director-General of the Association of Banks Dr. Adli Kandah that the impact of the global financial crisis is almost nonexistent on the banking system.

6 . the study of (tiles, 1996), As for the effects of the crisis on the Jordanian banking sector many of the officials of the Jordan stressed that the crisis that had an impact, the impact would be limited. , the high vulnerability of the economies of many countries of the world especially the developed world to recession and economic slowdown and that this would negatively affect our national economy through the impact on Many of the vital economic sectors Kalsadarat national tourism and remittances of Jordanians Workers abroad and thus impact negatively on economic growth in the Kingdom and the inability of the account Current balance of payments.

7. ( Shammari, Nazim,2009) Contemporary financial crisis, a liquidity crisis or the crisis of the system .. The fate of the crisis and its repercussions. "The study analyzed the international financial crisis.

\section{CHAPTER THREE}

\section{Conclusions and recommendations}

\section{Conclusions:}

1. The global financial crisis did not affect the profitability of the Jordanian banks were even in the high profitability of banks.

2. The global financial crisis affected the capital of the need to increase it to face future risks.

\section{Recommendations:}

1. to maintain the central Bey at the current level in the development of preventive measures of potential financial crises.

2. the local banks comply with the instructions of the Central Bank to avoid vulnerability to the global financial crisis.

3. Banks should be sure about each loan they give to be safe. 


\section{References:}

1.manual hinds-economic effects of financial crisis-1998.2. Richard W. - the mortgage crisis and its causes -2000 3. Reda Abu Hamad - Management Banking - Introduction Thalii quantitative contemporary - Dar Al-Fikr for printing, publishing and distribution - Jordan -2002.

4. Adli Kandah - Banks in Jordan Magazine - Issue X -2008.

5. Ziad Ramadan, Mahfouz Jaodh - contemporary trends in the management of banks - Dar Allowail for publication and distribution -2000.

6. Khalid al-Zubaidi - the performance of banks during the global financial crisis Paveing the way for reviving the jordanian economy

.7. Nazim al-Shammari - contemporary financial crisis, liquidity crisis or system crisis-2009.

8. Khalil Mohammed - Management Banking - Second Edition -1995. 